\title{
The Effect of Computer-Assisted Language Learning Project (CALLP) on Yemeni EFL Student Teachers' Perceived TPACK Self-Efficacy
}

\section{Mohialdeen Alotumi ${ }^{1 *}$}

* Correspondence:

mohialdeen@gmail.com

1. Department of English, Faculty of Languages, Sana'a University, Sana'a, Yemen

Received: 16 August 2020

Revision: 28 September 2020

Accepted: 11 October 2020

Published online: 20 December 2020 


\section{Introduction}

The fast and irrevocable developments in computer technologies made it possible for people around the world to communicate, do business, bridge cultural gaps, and get educated with fun (Alotumi, 2020; Pegrum, 2014). Their roles in all scopes of knowledge and training programs have been firmly established, especially in foreign language education (Kessler, 2018). This leads to a challenge on how to prepare future language teachers who can use technology in an effective, engaging, and innovative manner in their instruction (Kessler \& Hubbard, 2017). Addressing such a challenge, Mishra and Koehler (2006) put forward the Technological Pedagogical Content Knowledge (TPACK) framework for teacher educators to comprehend and delineate the types of knowledge necessary for teachers to teach with technology. TPACK renders the theoretical underpinnings to rationalize teachers' knowledge and skills for technology integration in instruction (Bostancığlu \& Handley, 2018).

In the TPACK framework, which is based on Shulman's (2016) construct of Pedagogical Content Knowledge (PCK) through the inclusion of technology, it is argued that the effective integration of technology for teaching specific content entails understanding and negotiating the relationships between pedagogy, content, and technology (Koehler et al., 2017). TPACK has, therefore, seven domains (see Figure 1).

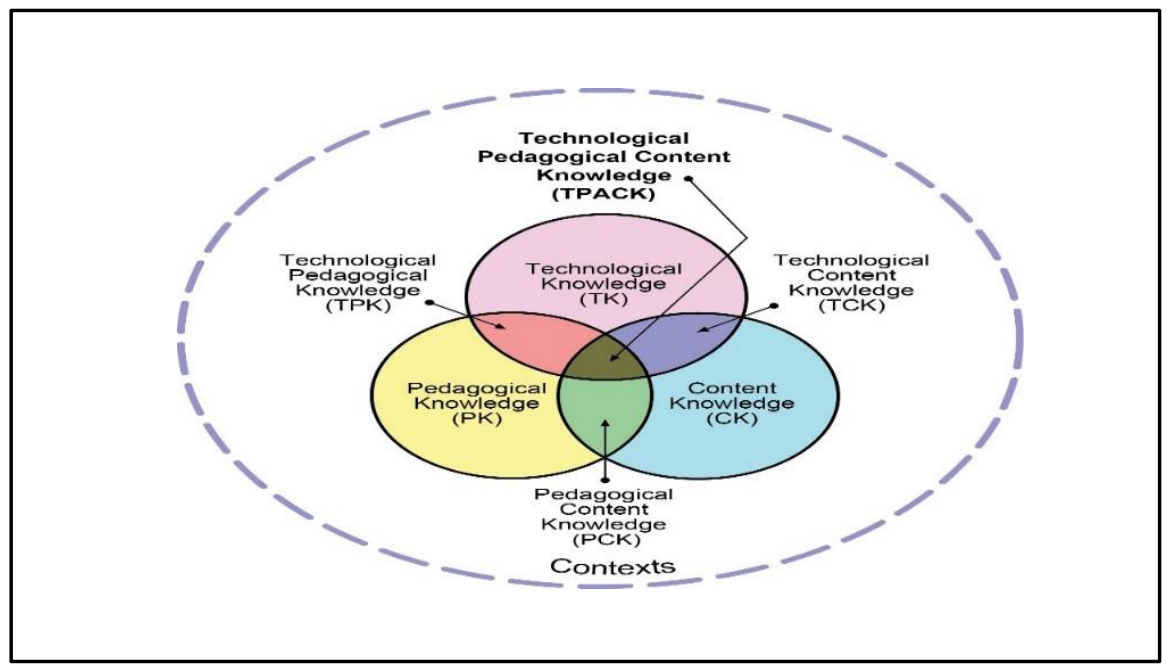

Figure 1. TPACK domains adapted from http://tpack.org.

The first component is Content Knowledge $(C K)$, which is defined as the knowledge of the subject matter to be taught by teachers i.e., what to teach. The second component, Pedagogical Knowledge (PK), concerns the knowledge of methodology i.e., how to teach the subject matter. The third component, Pedagogical Content Knowledge (PCK), deals with the knowledge of blending content (subject matter) and pedagogy (methods of teaching) to develop better teaching practices in the content areas. The fourth component, Technology Knowledge (TK), involves the knowledge about various technologies, ranging from low-tech technologies such as pencil and paper to digital technologies such as the Internet, computer applications, and interactive whiteboards. The fifth component, Technological Content Knowledge (TCK), indicates the knowledge of utilizing technology to create or supplement new representations for specific content. The sixth component, Technological Pedagogical Knowledge (TPK), is the knowledge of how various technologies can be utilized in teaching. The last component, Technological Pedagogical Content Knowledge (TPACK), refers to the knowledge required by teachers for integrating technology effectively into their teaching of the concerned subject matter.

Adapting TPACK, English Language Teacher Education Programs (ELTEPs) in Yemen offer their EFL student teachers with two technology-related courses: a computer course and an educational technology course. The computer course furnishes EFL student teachers with technical knowledge of computer hardware and software. The educational technology course provides them with technological-pedagogical knowledge of using various technology tools in general teaching practice. 
In fact, the ELTEPs of Yemen, and everywhere else, should take the full responsibility in equipping the future EFL teachers with the must-have TPACK for EFL instruction (EFL-TPACK), a contextualized TPACK which forms the conceptual framework for language teachers' knowledge base to integrate Computer-Assisted Language Learning (CALL) in EFL instruction (Baser et al., 2015; Bostancioğlu \& Handley, 2018; Fathi \& Ebadi, 2020; Joo et al., 2018; Pegrum, 2014; Son, 2018; Rahimi \& Pourshahbaz, 2019; Tai, 2015; Torsani, 2016; Turgut \& Boylan, 2017). According to Beatty (2010), CALL is broadly defined as a learner's utilization of a computer to boost his or her language proficiency.

Emphasizing the urgency of language teachers' knowledge of CALL in the digital era, Kessler and Hubbard (2017) pointed out, "teachers need knowledge of computer-assisted language learning (CALL) principles and practices and skill in adapting them to their own classroom settings" (p. 278). As a matter of fact, it is believed that language teachers cannot employ CALL in their classes if they do not have the necessary knowledge and skills to integrate technology in their instruction (Rahimi \& Pourshahbaz, 2019; Son, 2018). Accordingly, ELTEPs should address such necessity by integrating CALL across their curriculum (Fathi \& Ebadi, 2020; Mei et al., 2017; Murray, 2017; Park \& Son, 2020). To that end, the Computer Assisted Language Learning Project (CALLP) was implemented in the ELTEPs of four Yemeni public universities to engage EFL student teachers in a formal CALL training initiative.

\subsection{Statement of the Problem}

In Yemen, ELTEPs do not have any formal course of CALL as part of their curricula. Instead, they offer their EFL student teachers with two technology-related courses: a computer course and an educational technology course. These courses are general and have little pertinence to EFL instruction and thus may not be sufficient for EFL student teachers to develop their EFL-TPACK efficacy (El Shaban \& Egbert, 2018; Kessler \& Hubbard, 2017; Schmid, 2017; Son, 2018). Since recent studies have yielded mixed findings on the impact CALL-oriented training on student teachers' TPACK self-efficacy (Le \& Song, 2018; Tai, 2015), and since student perceptions are dynamic and shaped by the change rate in technology self-efficacy (Lai et al., 2014; Lee et al., 2011), this study came to investigate Yemeni EFL prospective teachers' perceptions of their TPACK self-efficacy before and after the specialized CALL training offered by CALLP.

\subsection{Purpose of the Study}

The present study aims to examine the effect of CALLP on Yemeni EFL student teachers' efficacy using the EFL student teachers' TPACK Self-assessment Survey, known as TPACK-EFL, developed by Baser et al. (2015). In line with this objective, the study specifically focuses on the following research questions:

What are the Yemeni EFL student teachers' perceptions of their TPACK self-efficacy pre-CALLP with reference to TPACK domains of CK, PK, PCK, TK, TCK, TPK, and TPACK?

What are the Yemeni EFL student teachers' perceptions of their TPACK self-efficacy post-CALLP with reference to TPACK domains of CK, PK, PCK, TK, TCK, TPK, and TPACK?

Is there any significant difference in Yemeni EFL student teachers' perceived overall TPACK self-efficacy pre-and post-CALLP?

What are the Yemeni EFL student teachers' attributions of their increased or decreased perceptions of TPACK selfefficacy?

\subsection{Research Hypothesis}

Based on the above questions, the following null hypothesis was generated:

H0: There is no significant difference between EFL student teachers' perceived overall TPACK self-efficacy pre- and post-CALLP.

\section{Review of the Literature}

\subsection{TPACK Self-Efficacy}

Perceived self-efficacy is defined as an individual's "beliefs about their capabilities to produce designated levels of performance that exercise influence over events that affect their lives" (Bandura, 1994, p.2). Teacher self-efficacy refers to teachers' personal beliefs about their pedagogic knowledge and skills. Self-efficacy is a credible indicator of 
teacher behavior (Kent \& Giles, 2017), student teachers' learning behaviors (Koh, 2011), as well as their degree of anxiety or confidence levels. EFL-TPACK self-efficacy refers to teachers' personal beliefs regarding their abilities to effectively integrate technology in their EFL instruction (Baser et al., 2015; Bostancioğlu \& Handley, 2018; Setyowati Ciptaningrum, 2017; Rahimi \& Pourshahbaz, 2019; Tai, 2015). Research studies have established the importance of positive perceptions of TPACK self-efficacy on teacher effectiveness in integrating technology in their instruction (Joo et al., 2018; Koh \& Chai, 2014; Mei et al., 2017; Tseng et al., 2019). Those teachers with higher TPACK selfefficacy were more likely to utilize technology in their instruction (Joo et al., 2018; Kartchava \& Chung, 2015; Teo et al., 2018).

Evidently, student teachers' perceptions of their EFL-TPACK competencies are essential to their future utilization of CALL for EFL instruction. If a piece of CALL is perceived uncomplicated, teachers are more likely to develop a stronger intention to use it (Ince, 2017; Joo et al., 2018). Conversely, if the same computer technology is perceived to be complicated, teachers are more likely to manifest resistance (Akayoğlu, 2017; Mohammadzadeh \& Salem, 2018). In this regard, Teo et al. (2018) accentuated that having strong TPACK is conducive to the use of Web 2.0 technologies for instructional purposes.

Highlighting the importance of EFL-TPACK CALL training, Chambers and Bax (2006) pointed out that teachers' lack of proper training is one of the important factors which have a negative impact on the normalization of CALL. Correspondingly, Kessler and Hubbard (2017) advised that teacher educators should first possess CALL competency so that the normalization of CALL can be viable in teacher education. Similarly, Son (2018) accented that one of the primary goals of language teacher education is to help student teachers develop their CALL knowledge and skills.

To maintain positive perceptions of their TPACK self-efficacy, and thus improving their technology use, student teachers should be provided with proper CALL training to develop their CALL self-efficacy (Ersanli, 2016; Fathi \& Ebadi, 2020). Moreover, teacher educators should frequently utilize CALL in their classes so that student teachers can be exposed to various experiences of CALL integration (Kessler \& Hubbard, 2017; Mei et al., 2017; Park \& Son, 2020; Son, 2018). According to Kessler (2018), it is highly important that formal teacher education encompasses proper means to provide prospective teachers with the abilities to use technology and to boost their mindset to critically evaluate their technology use for teaching and learning.

It has also been reported that teachers' perceptions do not only impact their personal decisions and experiences with technology but also those of their students (Admiraal et al., 2016; Hlas, 2017). And, since technology keeps changing at a rapid pace and thus rendering some applications outdated, student teachers, especially in a technology-based course, look to their educators for "guidance on what technology to use, when, and how" (Murray, 2017, p.171). They perceive their educators as role models whom they consider as an inspiration for technology integration and an insightful source of modeling technology utilization and reflecting upon experiences of technology use (Admiraal et al., 2016).

\subsection{Previous Studies on TPACK Self-Efficacy in ELTEPs}

Though there are many studies focusing on TPACK integration in teacher education in general, a few recent studies have investigated the impact of CALL integration on EFL student teachers' perceived TPACK self-efficacy (CALL competencies) in the ELTEPs of various international contexts. Akayoğlu (2017), for instance, looked into Turkish EFL student teachers' perspectives towards a CALL course. He utilized content analysis method to analyze students' blog posts reflecting on a 14-week-CALL course. He found that after taking the CALL course, the participants' anxiety level towards CALL had changed and they felt more confident about CALL tools. Furthermore, the participants indicated that the CALL course should have been offered at an earlier grade of the undergraduate program.

Ersanli (2016) explored the impact of a five-week workshop on EFL student teachers' TPACK. He employed a TPACK survey and journal entries to collect data from 59 student teachers of a Turkish state-university ELTEP. Through descriptive and inferential statistics, the findings of his study revealed a statistically significant improvement in both male and female student teachers' overall TPACK level as well as in the TPACK domains. Also, student teachers were found to display better performance in creating and adapting language learning and teaching materials with specific goals.

İşler and Yıldırım (2018) investigated Turkish EFL student teachers' perceptions of their TPACK competencies. They also looked into the factors influencing student teachers' TPACK perceptions and their beliefs towards technology integration into EFL instruction. They employed a TPACK questionnaire and interviews to collect data from 94 
student teachers in a Turkish public-university ELTEP. Using descriptive statistics and content analysis, their findings revealed that participants had a satisfactory level of TPACK competencies. Additionally, personal interest, experience, knowledge, and access were found affecting factors associated with student teachers' development of TPACK.

Jeong (2017) examined EFL student teachers' perspectives on CALL integration in a Korean ELTEP. She used an online 5-point Likert-scale questionnaire to collect data from a sample of $82 \mathrm{EFL}$ student teachers. She also conducted semi-structured focus group interviews with nine student teachers. The findings of her study revealed that CALL integration could boost EFL student teachers' confidence and competence in developing technological skills and pedagogical expertise. It was also found that though the participants had positive perceptions of CALL integration, they reflected concerns about integrating CALL in their future EFL instruction such as their national educational system that focused on preparing students for the university entrance examination.

Joo et al. (2018) looked into EFL student teachers' perceptions to examine structural relationships between TPACK, teacher self-efficacy, perceived ease of use, perceived usefulness, and their intentions to use technology for instructional purposes. They used a questionnaire to collect data from 300 student teachers in the college of education of three Korean universities. Employing the structural equation modeling methods, their findings indicated that student teachers' TPACK positively affected their perceived ease of use and perceived usefulness. They also reported that though teacher self-efficacy, perceived ease of use, and perceived usefulness affected student teachers' intention to use technology, their TPACK did not directly influence their intention to use technology.

Kwangsawad (2016) examined EFL student teachers' competencies to harness TPACK in their practicum by measuring their abilities in the seven domains of TPACK. He used TPACk self-reporting survey, lesson plan assessment, and classroom observations to collect data from a sample of 33 EFL student teachers in an ELTEP in Thailand. The findings of his study indicated that student teachers scored high for all TPACK domains. Thus, the ELTEP was successful in equipping them with TPACK knowledge that could be used to apply and foster the interplay between technology, content, and pedagogy.

Le and Song (2018) looked into the effects of a CALL course on Vietnamese EFL student teachers' TPACK level and examined their attitudes towards technology integration in language instruction. They used a pre- and post-surveys and semi-structured interviews to collect data from a purposive sample of 42 EFL student teachers. The findings of their surveys evinced that though there was a relative increase in student teachers' TK, TPK, TPACK, such increase was not a significantly significant difference in student teachers' TPACK. It was also found that participants with more teaching experience felt more confident in their integration of TPACK in language instruction. Further, the participants' attitudes towards CALL integration were influenced by educational policy, facilities, and their teaching philosophy.

Mei et al. (2017) analyzed EFL student teachers' perceptions of factors influencing their intention to adopt Web 2.0 technologies for EFL learning. They employed structural equation modelling with data collected from $295 \mathrm{EFL}$ student teachers enrolled in a Chinese ELTEP. Their findings indicated that participants' intention to harness CALL 2.0 was predicted most strongly by facilitating conditions such as support and access. They concluded that increasing student teachers' beliefs in the benefits of CALL 2.0 relied on changing the facilitating conditions in the environments of schools and teacher education.

Prasojo et al. (2018) examined EFL student teachers' perceptions of ICT integration during their teaching practicum in an ELTEP in Indonesia. They used qualitative inquiry with a case study approach focused on video-based observations and focus group discussions for collecting data from a sample of 60 EFL student teachers. Their findings showed that though participants had good ICT competency level and experience and reflected positive perceptions of ICT benefits for EFL instruction, they did not employ ICT in their teaching practices due to school conditions.

Turgut and Boylan (2017) conducted a longitudinal cross-sectional study to describe EFL student teachers' selfperceived TPACK development in an ELTEP in the southern part of Turkey. She used a mixed-method TPACK survey to collect data from 174 EFL student teachers-sophomores $(n=66)$, juniors $(n=55)$, and seniors $(n=53)$. The findings of her study revealed that the TPACK approach helped participants improve their confidence and competence in productive technology integration over the course of time. Additionally, it was found that student teachers' TPACK development was in a nonlinear pattern.

Tseng et al. (2019) scrutinized the effect of context on six EFL student teachers' TPACK enactment in Taiwan. They also aimed to understand how student teachers considered contextual factors in applying web conferencing technology 
to EFL learning and teaching over the course of 14 weeks. They collected data from six EFL student teachers, 14 firstyear senior high school students, one collaborative school-based teacher, and three professors. They utilized quantitative content analysis of coded post-teaching discussions and qualitative analysis of interviews. The findings of their study revealed that though participants' discussions were oriented towards PCK, as opposed to TK, their discussions were particularly not associated with TPK. Moreover, their findings indicated that sound-quality technical problems and teachers' concerns about their students' prior knowledge were the two prominent contextual factors influencing the student teachers' web-conferencing teaching.

\section{Methodology}

This descriptive study is of a quasi-experimental nature since its participants were not randomly assigned to the treatment. It utilized a one-group pre-test-post-test design and employed a mixed-method approach i.e. a mixture of both quantitative and qualitative methods were used to collect data on the population of EFL student teachers at staterun universities in Yemen. This triangulation of data collection using mixed methods produces consummate and useful findings. According to Creswell and Creswell (2018), the combination of quantitative and qualitative methods in a study yields optimal data addressing research inquiry.

\subsection{Design of the Study}

The present study adopted a one-group pre-test-post-test design. It employed a mixed-method approach to data collection, depending on participants' self-reporting of their TPACK self-efficacy pre- and post-CALLP.

\subsection{Participants}

The target population of this study included all EFL student teachers attending ELTEPS across Yemen. Since CALLP was implemented only in four public universities, the study population included all EFL level-4 student teachers attending CALLP in four different ELTEPs in the academic year of 2017-2018. One hundred participants from each university were selected through systematic sampling procedure-each second name on the roster of EFL level-4 student teachers was selected. The participants of the true representative sample totaled 400 homogeneous student teachers $(N=400)$. They responded to the same questionnaire pre- and post-CALLP. Their mean age was 24 , ranging from 23 to 29. Sixty-five percent of the participants were females.

For qualitative data, four male student teachers and four female student teachers from those who responded to the questionnaire in each ELTEP were selected based on their willingness to partake in semi-structured interviews. Thirtytwo student teachers were asked the same set of questions during the interviews - with little room for on-the-spot questions to gain more clarification.

\subsection{CALLP Workshops}

Supported by the Fulbright Program and sponsored by the US Department of State, CALLP was carried out in the second semester of the academic year of 2017-2018 in four ELTEPs of four Yemeni public universities, namely, Sana'a University, Dhamar University, Ibb University, and Hodeidah University. It aimed at acquainting Yemeni EFL level-4 student teachers with some of the latest concepts and skills of CALL. It rendered five intensive EFL-TPACK CALL workshops for each ELTEP (see Appendix A for the outline of CALLP workshops). The student teachers in each ELTEP received the same CALLP workshops by the same CALL trainer (the researcher). Each workshop lasted for 4 hours (with a 30-minute break) and followed the steps proposed in the TPACK-in-Action model (Tai, 2013): (1) Modeling; (2) Analyzing; (3) Demonstrating; (4) Application; and (5) Reflection (see Figure 2). 


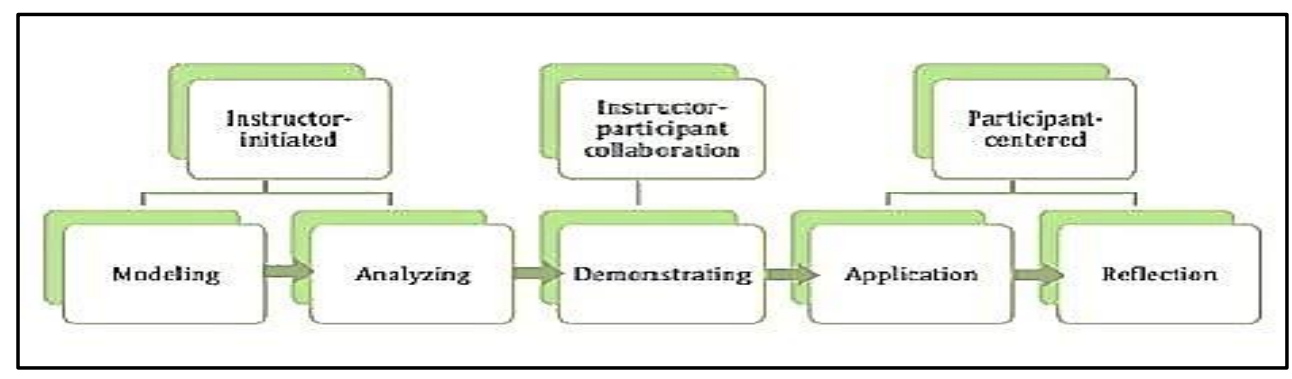

Figure 2. TPACK-in-action model adapted from Tai (2013).

\subsection{Instruments}

Two instruments were used to collect data from the participants: (1) a survey and (b) an interview. The survey consisted of two sections (see Appendix B). The first of which covered student teachers' demographic information, including age, gender, and willingness to partake in a CALL interview. The second section was the TPACK-EFL selfassessment questionnaire developed by Baser et al. (2015).

TPACK-EFL questionnaire comprised seven subscales corresponding to TPACK afore-mentioned components. It contained 39 Likert-type items (statements), ranged from strongly disagree $=1$, to disagree $=2$, don't know $=3$, to agree $=4$, to strongly agree $=5$. Items 1-9 measured student teachers' perceived TK self-efficacy. Items 10-14 assessed their perceived CK self-efficacy. As regards their perceived PK self-efficacy, it was gauged using items 1520. Concerning items 21-25, they were structured to evaluate student teachers' PCK self-efficacy while items $26-28$ examined their TCK self-efficacy. With reference to items 29-35, they were designed to quantify student teachers' perceived TPK self-efficacy. The last four items (items 36-39) looked into their TPACK self-efficacy. In terms of reliability, the seven TPACK domains in the instrument gained high internal reliability (Cronbach's $\alpha>.80)($ Baser et al., 2015). For assessing participants' perceived self-efficacy, their perceptions of each subscale were measured with a range of possible mean scores (between 1 and 5), with higher scores indicating higher level of self-efficacy.

For the interviews, a semi-structured interview form was created and developed, focusing on EFL student teachers' perceptions of their TPACK self-efficacy (see Appendix C). The purpose of the interview was to substantiate the data obtained through the TPACK-EFL survey. It also aimed to get the respondents to express their views on CALLP and the attributions of their TPACK self-efficacy change.

Concerning face validity and content validity of the TPACK-EFL survey, it was validated through experts and EFL student teachers' reviews, and then through exploratory factor analysis (Baser et al., 2015). For the interview question form, it was given to a panel of three professors of applied linguistics at Sana'a University to examine the validity of its items. Their insightful feedback was utilized to remove, add, and modify the interview instrument items prior to carrying out the study.

In terms of reliability, the Cronbach's coefficient alpha value for all the items on the TPACK-EFL survey ranged from .81 to .92 (Baser et al., 2015), indicating the items were of high reliability (Cohen et al., 2018). According to Baser et al. (2015), the Cronbach's alpha values for the subscales of TPACK-EFL survey were .89 for TK (highly reliable), .88 for CK (highly reliable), .92 for PK (very highly reliable), .91 for PCK (very highly reliable), .81 for TCK (highly reliable), .91 for TPK (very highly reliable), and .86 for TPACK (highly reliable).

\subsection{Procedures of Data Collection}

After making all necessary arrangements through communications with the concerned Heads of English Departments (HoEDs), the researcher traveled to the selected universities. He spent a week conducting the scheduled CALLP training workshops for EFL level-4 student teachers in each of the four ELTEPs.

On the first day of arrival in each ELTEP, the researcher met with the HoED to further discuss CALLP activities. Afterwards, and before commencing CALLP, the selected EFL level-4 student teachers were gathered in a lecture hall and did the pre-CALLP TPACK-EFL questionnaire. After finishing CALLP workshops, the same selected student teachers did the same questionnaire. Both questionnaires were administered by the researcher himself with the help 
of HoEDs and timed equally (60 minutes). Therefore, the return rate and valid response rate for both questionnaires were $94-97 \%$, indicating a high valid response rate (see Table D for each university response rate).

After administering the post-CALLP TPACK-EFL survey in each ELTEP, those who indicated their willingness to participate in a CALLP interview were assigned numbers and listed as per gender (male/female). Then, four male student teachers and four female student teachers were randomly selected and interviewed. Each interview was in English and lasted for 15 -20 minutes. All interviews were recorded after obtaining verbal consent from each interviewee.

\subsection{Data Analysis Procedure}

Data from the questionnaires were analyzed utilizing both descriptive and inferential statistics (see

Table E). Descriptive statistics (mean and standard deviation) were employed to describe and summarize the data collected from the study sample, whereas inferential statistics (paired-samples $t$ test and effect size) were employed to utilize the sample data statistics to make inferences about the population parameters (Cohen et al., 2018).

Since the same group was examined twice on their perceived TPACK self-efficacy through the TPACK-EFL questionnaire pre- and post-CALLP, the analysis procedure employed was a paired-samples $t$ test (Cohen et al., 2018). The paired-samples $t$ test examines whether the score distribution of the group is statistically significantly different. It relies on four main assumptions about the obtained scores (Cohen et al., 2018). The first assumption is that the scores are interval or ratio. Obviously, the scores obtained in this study are interval. The second assumption is that the scores are acquired from observations that are independent of one another. In this study, the scores were obtained from the same group using the same instrument, during two independent sessions-pre- and post-CALLP. The third assumption is that such scores are normally distributed. Shapiro-Wilk Test was applied to examine whether the scores are approximately normally distributed. It indicated that the scores of the paired samples are not significantly different from a normal distribution - the Sig. value on the test of the score difference of pre- and post-CALLP were greater than .05 (see Figure F1). The fourth assumption is that the scores should not contain any outliers. A boxplot of the study scores showed visually that the study scores are without outliers (see Figure F2).

The effect size, defined as an estimate of effect magnitude in the population, was calculated in line with "Formula 11.10 " for paired design suggested by Cumming (2012, p. 291). The outcome of the effect size equation, reported at the significance level of 0.05 , was interpreted according to Cohen's (1992) proposed guidelines such that $r=.10$ is small effect size, $r=.30$ is medium effect size, $r=.50$ is large effect size.

The qualitative data acquired through the interviews were analyzed according to Creswell and Creswell's (2018) suggested guidelines for the coding process. Correspondingly, all the recorded interviews were literally transcribed, utilizing anonyms for the 32 interviewees. Next, an in-depth reading of all the transcripts was fulfilled to assort the responses in light of the research questions. Then, codes were analytically evolved within each group using repetitive words, phrases, patterns, and notions. Afterward, those codes were designated into coding categories, with relevant codes converted into broader categorical themes. Last, pertinent quotations were grouped under their apposite coding categories.

All quantitative data analyses were done by using the Statistical Package for the Social Sciences (SPSS) version 20 to determine the relationships between the independent variable and the dependent variables. By convention, an alpha level of 0.05 was used as the criterion for statistical significance. The interview data were analyzed with MAXQDA (v. 11), a qualitative-data-analyzing software application.

\section{Findings}

\subsection{Findings from the Survey}

To answer the first and the second research questions, addressing student teachers' perceptions of their TPACK selfefficacy pre- and post-CALLP, descriptive statistics have been calculated to indicate the mean and standard deviation of the participants' responses to the pre- and post-CALLP questionnaires. Table 1 reports the mean and standard deviation for the pre- and post-CALLP TPACK domains and TPACK-EFL, while Table 2 presents the score category breakdown used in the interpretation of the level of means. 
As Table 1 illustrates, respondents' perceived overall level of pre-CALLP TPACK self-efficacy was moderate with an overall mean score of 3.37 ( $S D=0.83$ ) while their perceived overall level of post-CALLP TPACK self-efficacy was high with an overall mean score of $3.95(S D=0.59)$. This finding reveals a substantial increase in student teachers' EFL-TPACK self-efficacy level after they partook in CALLP. Such an increase was evident within the technologyrelated TPACK domains, namely, TK (pre-CALLP $M=3.23, S D=0.85$; post-CALLP $M=3.73, S D=0.52$ ), TCK (Pre-CALLP $M=3.07, S D=0.90$; post-CALLP $M=3.84, S D=0.76$ ), TPK (pre-CALLP $M=2.85, S D=0.87$; postCALLP $M=4.01, S D=0.56$ ), and TPACK (pre-CALLP $M=2.83$, $S D=0.86$; post-CALLP $M=4.23, S D=0.68$ ).

Table 1. Comparisons of group means and standard deviations for TPACK-EFL scale score

\begin{tabular}{llllll}
\hline \multirow{2}{*}{ Scale } & \multicolumn{3}{c}{ Pre-CALLP } & & \multicolumn{2}{c}{ Post-CALLP } \\
\cline { 2 - 3 } \cline { 5 - 6 } & $M$ & $S D$ & & $M$ & \\
\hline TK & 3.23 & 0.85 & & 3.73 & 0.52 \\
CK & 3.80 & 0.83 & & 3.88 & 0.57 \\
PK & 3.77 & 0.64 & & 3.83 & 0.51 \\
PCK & 4.06 & 0.87 & & 4.14 & 0.53 \\
TCK & 3.07 & 0.90 & & 3.84 & 0.76 \\
TPK & 2.85 & 0.87 & & 4.01 & 0.56 \\
TPACK & 2.83 & 0.86 & & 4.23 & 0.68 \\
TPACK-EFL & $\mathbf{3 . 3 7}$ & $\mathbf{0 . 8 3}$ & $\mathbf{3 . 9 5}$ & $\mathbf{0 . 5 9}$
\end{tabular}

Note. $\mathrm{TK}=$ Technological Knowledge, $\mathrm{CK}=$ Content Knowledge, $\mathrm{PK}=$ Pedagogical Knowledge, $\mathrm{PCK}=$ Pedagogical Content Knowledge, TCK $=$ Technological Content Knowledge, TPK= Technological Pedagogical Knowledge, TPACK= Technological Pedagogical Content Knowledge

Table 2. Mean score category breakdown

\begin{tabular}{ll}
\hline Means & Corresponding level \\
\hline $1.0-1.80$ & Very low \\
$1.81-2.60$ & Low \\
$2.61-3.40$ & Moderate \\
$3.41-4.20$ & High \\
$4.21-5.0$ & Very high \\
\hline
\end{tabular}

To answer the third research question, regarding the impact of CALLP on student teachers' perception of TPACK self-efficacy, the paired-samples $t$ test was conducted on the participants' overall perceptions of pre- and post-CALLP TPACK-EFL questionnaire. The outcome of the $t$ test and effect size indicates that the obtained difference in student teachers' perceived overall self-efficacy on pre- and post-CALLP TPACK-EFL questionnaire was statistically significant, $t=22.680, p<.001, r=.41$ (see Tables $3 \& 4$ ). Accordingly, the null hypothesis can be rejected. This implies that CALLP might have greatly assisted student teachers in improving their level of TPACK efficacy for EFL instruction. Moreover, the results of the $t$ test demonstrated that the obtained difference in student teachers' perceived self-efficacy on the TPACK-EFL subscales was statistically significant only on the technology-related domains of TPACK, namely, TK, TCK, TPK, and TPACK (see Figure F3). 
Table 3. Significant difference in student teachers' pre- and post-CALL perceived overall TPACK self-efficacy

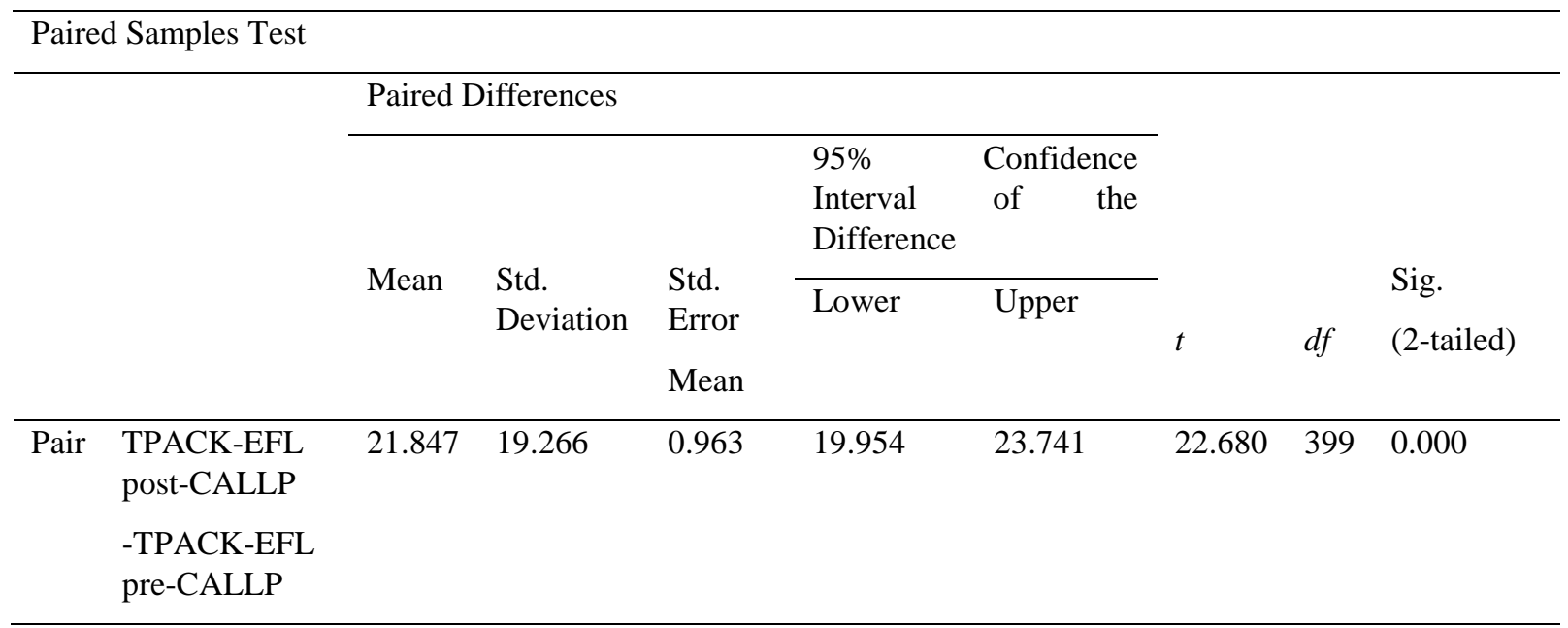

Table 4. Effect size on student teachers' perceived overall TPACK self-efficacy

\begin{tabular}{lc}
\hline Cohen's $d$ & Corresponding $r$ \\
\hline$d=.90$ & $r=.41$ \\
\hline
\end{tabular}

\subsection{Findings from Interviews}

Regarding the fourth research question, there were seven emerging themes for student teachers' TPACK self-efficacy change: Positive CALLP impact, CALL integration models, exposure to various pedagogy-oriented technology tools, hands-on experience with content fine-tuning technology tools, technology knowledge enhancement, inconsistency of ELTEP technology courses with students' needs, and ELTEP's limited CALL use (see Table 5).

The first theme, CALLP positive impact, reflects student teachers' satisfaction with CALLP. Almost 91\% of the participants expressed positive perceptions of CALLP. During the workshops, participants were engaged in CALL sessions fraught with up-to-date knowledge and skills. Such exposure to the latest in CALL seemed to positively affect participants' overall perceptions of CALLP with reference to their TPACK confidence and competence.

The second, third, fourth, and fifth themes address student teachers' self-efficacy change respectively with reference to TPACK, TPK, TCK, and TK, corroborating the findings from the TPACK-EFL survey. The second theme, CALL integration models, refers to student teachers' TPACK gain through modeling of CALL use. Approximately $88 \%$ of the respondents indicated that the models presented in CALLP workshops helped them improve their TPACK selfefficacy. The third theme, exposure to various pedagogy-oriented technology tools is characterized as student teachers' TPK gain through exposure to different technology tools for instructional purposes. Slightly more than $81 \%$ of the participants believed that the variety of educational technology tools presented in CALLP had enhanced their TPK. The fourth theme, hands-on experience with content fine-tuning technology tools, describes student teachers' TCK gain through experiencing CALL tools for manipulating EFL content. Seventy-five percent of the respondents delineated that trying technology tools for manipulating content in CALLP contributed to the improvement of their TCK. The fifth theme, technology knowledge enhancement, denotes student teachers' TK gain through learning new technology concepts and applications. Almost $72 \%$ of the participants interpreted their increased TK self-efficacy as the outcome of their knowledge gain through learning new technical concepts and skills in CALLP.

In addition, the sixth and seventh themes provide insights into the technology courses and CALL integration in ELTEPs. The sixth theme, inconsistency of ELTEP technology courses with students' needs, reflects student teachers' 
dissatisfaction with ELTEP technology courses. Approximately $66 \%$ of the respondents voiced their concerns that the technology courses furnished in their ELTEPs are not enough to prepare them to integrate CALL in their future EFL classes. Finally, the seventh theme, ELTEP's limited CALL use, stands for student teachers' inadequate exposure to CALL in ELTEP. Slightly more than $59 \%$ of the participants revealed that their teacher educators' use of CALL is limited to basic computer software and applications such as MS PowerPoint for presentation and Internet browser for getting authentic and non-authentic EFL materials.

Table 5. Attribution to student teachers' TPACK self-efficacy change

\begin{tabular}{|c|c|c|c|c|c|c|}
\hline Theme & & Definition & & $f$ & $\%$ & Sample quotation \\
\hline $\begin{array}{l}\text { Positive } \\
\text { impact }\end{array}$ & CALLP & $\begin{array}{l}\text { Student } \\
\text { satisfaction } \\
\text { CALLP }\end{array}$ & $\begin{array}{r}\text { teachers' } \\
\text { with }\end{array}$ & 29 & 90.63 & “ \\
\hline
\end{tabular}

CALL integration Student teachers' $28 \quad 87.50$

models TPACK gain through modeling of CALL use
CALLP workshops have exposed us to a lot of ideas, concepts, and skills of technology use for EFL teaching, we weren't aware of! Besides, I feel more confident in using technology now than before. And I feel really glad that I attended all of the workshops."

"Well, after observing the models provided in the intensive workshops for the four skills of English, I can tell you that I feel more competent in using different computer programs in my method of teaching English."

"Getting to know many educational computer programs and how they can be used in teaching, I believe that my knowledge has improved. And, since we have many options in terms of computer programs, we can properly choose and employ various programs as part of the methodology to make English classes more fun."

"The new programs that we have tried in the workshops to create and modify content made me feel more prepared to use technology to modify content to suit my lesson objectives and present it to the class in a more interesting way." 


$\begin{array}{lllll}\begin{array}{l}\text { Technology } \\ \text { knowledge } \\ \text { enhancement }\end{array} & \begin{array}{l}\text { Student teachers' TK } \\ \text { gain through learning } \\ \text { new technology } \\ \text { concepts }\end{array} & 71.88 \\ & \text { applications } & & \\ & & & \\ & & & & \\ \text { Inconsistency of } & \text { Student teachers' 21 } & 65.63 \\ \begin{array}{l}\text { ELTEP technology } \\ \text { courses wissatisfaction with } \\ \text { students' needs with }\end{array} & \begin{array}{l}\text { ELTEP technology } \\ \text { courses }\end{array}\end{array}$

$\begin{array}{lllll}\text { ELTEP's } & \text { limited } & \begin{array}{l}\text { Student teachers' } \\ \text { inadequate exposure to }\end{array} & & 59.38 \\ \text { CALL use } & & \begin{array}{l}\text { CALL in ELTEP } \\ \end{array} & & \end{array}$

\begin{abstract}
"Through CALLP, we had the chance to get acquainted with new computer applications and technical terms such as Second Life, Moodle, LMS, VOIP, etc."
\end{abstract}

"Frankly, I feel that I need more training regarding CALL. The computer course that we had is not enough because it is technical! I mean basic things that we already knew, like how to create a file, how to access a file and a website, how to create a document, etc. For the educational technology course, well, it is general and is not really linked to EFL teaching. Other students from other departments take the same two courses."

"Out of my study experience in the English Department, I can tell you that using CALL is limited. Some of our professors have used PowerPoint to present some lesson aspects through data show. Also, they have used the Internet to get materials for classes."

\section{Discussion}

\subsection{Impact of CALLP}

The first research question of the present study was, "What are the Yemeni EFL student teachers' perceptions of their TPACK self-efficacy pre-CALLP with reference to TPACK domains of CK, PK, PCK, TK, TCK, TPK, and TPACK?" Based on the quantitative data findings, student teachers had a self-reported moderate level of pre-CALLP TPACK self-efficacy in all the domains of TPACK, except for PCK, which was perceived as a high level. This finding suggests ELTEPs have been conventional and tailored towards Shulman's (2016) PCK. In other words, though technology courses are somehow taught in ELTEPs, they have not been designed to integrate the technology in ELTEPs extensively with EFL in mind. They may not provide student teachers with sufficient hands-on experiences with technology utilization in EFL. This finding is congruous with Fathi and Ebadi (2020), and Park and Son (2020), highlighting the necessity for extended and practical CALL experiences in ELTEPs.

The second research question was, "What are the Yemeni EFL student teachers' perceptions of their TPACK selfefficacy post-CALLP with reference to TPACK domains of CK, PK, PCK, TK, TCK, TPK, and TPACK?" According to the quantitative findings, student teachers report a high-to-very-high level of post-CALLP TPACK self-efficacy in all the technology-related domains of TPACK. This finding was corroborated by the interview results that echo student teachers' self-efficacy change with reference to the technology-related domains of TPACK. This finding underlines that though CALLP was short-termed, it helps student teachers boost their knowledge and skills in specialized technology integration in ELTEPS. Through CALLP, they could address the gap in their knowledge of TPACK-EFL, thus increasing their self-efficacy. Such a finding is in line with Fathi and Ebadi (2020) and Park and Son (2020) that EFL CALL training contributes to enhancing student teachers' confidence in linking technology and EFL.

The third research question was, "Is there any significant difference in Yemeni EFL student teachers' perceived overall TPACK self-efficacy pre-and post-CALLP?" The relevant finding revealed that the proposed null hypothesis is rejected. In other words, there is a significant difference in EFL student teachers' perceived overall TPACK selfefficacy pre- and post-CALLP. Such a statistically significant difference was evident only in the technology-related 
domains of TPACK, namely, TK, TCK, TPK, and TPACK. Such a finding was substantiated by expressed satisfaction and the perceived positive CALLP impact, particularly on the technology-related domains of TPACK, voiced by most of the interviewees. This finding demonstrates that CALLP does have a positive effect on student teachers' TPACK self-efficacy. In this respect, the findings showed that though most student teachers had a moderate level of perceived overall TPACK self-efficacy pre-CALLP, they reflected a significantly high perceived overall TPACK self-efficacy after taking part in CALLP. Such an improvement was significant in the technology-related domains of TPACK, namely, TK, TCK, TPK, and TPACK. Such findings are in line with Ersanli (2016), Joo et al. (2018), and Tseng et al. (2019) that CALL training had a positive impact on EFL student teachers in the development of their EFL-TPACK competency.

\subsection{Attributions of Increased TPACK Self-Efficacy}

The fourth research question was, "What are the Yemeni EFL student teachers' attributions of their increased or decreased perceptions of TPACK self-efficacy?" The relevant qualitative findings indicated that student teachers perceived that the technology courses offered in their ELTEPs and the exposure to CALL tools was not gratifying to make them feel well-prepared to use CALL. In this respect, CALLP did help EFL student teachers aid their awareness of CALL tools and develop their confidence in using CALL. Such findings corroborate those of Akayoğlu (2017), Hlas (2017), Ince (2017), Jeong (2017), Kwangsawad (2016), Mei et al. (2017), Tai (2015), and Turgut and Boylan (2017) that proper CALL training is crucial to help EFL teachers develop positive beliefs of their TPACK self-efficacy since they need to feel comfortable and competent at using CALL.

\subsection{Implications and Recommendations}

The findings of this study imply a pressing need to grow awareness and further TPACK efficacy among student teachers so that they are competently empowered to utilize CALL and its tools - which impressively get smarter day by day - not only through up-to-date CALL workshops but also through having a CALL-dedicated course as part of ELTEP. In fact, TPACK efficacy has sway on student teachers' intention to adopt and employ CALL for future EFL instruction (İşler \& Yıldırım, 2018; Joo et al., 2018; Mei et al., 2017; Rahimi \& Pourshahbaz, 2019). If these student teachers are expected to adopt and utilize CALL in their future EFL classes, ELTEP policymakers should take serious action to pedagogically inform and raise awareness about CALL among EFL student teachers, and not just educate them on technology. Thus, it is highly recommended that a CALL course should be integrated into the ELTEP curriculum.

Furthermore, teacher educators are models to their students, and their consistent use of various CALL tools in ELTEP provides paramount exposure and observable experience. In this way, they positively contribute to the enhancement of their students' TPACK self-efficacy (Admiraal et al., 2016; El Shaban \& Egbert, 2018; Hlas, 2017; Tseng et al., 2019). Therefore, teacher educators should harness assorted CALL tools in their classes so that student teachers can observe the utilization of CALL.

\section{Conclusion}

The focus of this study was to explore the effects of CALLP on Yemeni EFL student teachers' TPACK self-efficacy. It also attempted to determine any significant difference in students' teachers' TPACK self-efficacy pre- and postCALLP. The findings from the TPACK-EFL scale and interviews suggested a significant improvement in EFL student teachers' overall TPACK self-efficacy after partaking in CALLP. The betterment was conspicuous in the technologyrelated domains of TPACK (i.e., TK, TCK, TPK, and TPACK). In general, this study renders evidence that EFLTPACK CALL training holds a great promise for student teachers and CALL integration into ELTEPs. For, student teachers' TPACK-EFL self-efficacy ameliorated after taking part in CALLP workshops. Based on the findings of this study, it can be suggested that while CALL integration is paramount in ELTEPs, EFL student teachers need many hands-on opportunities and a kind of internship to foster their TPACK-EFL self-efficacy to be in a better position to utilize technology within EFL instruction appropriately and effectively.

\subsection{Study Limitations and Suggestions for Further Research}

This study had two limitations. First, it employed a one-group pre-test-post-test design, depending on participants' self-reporting of their TPACK self-efficacy pre- and post-CALLP. Replicating this study utilizing a pre-test-post-test control and experimental group design would help ascertain the generalizability of the findings from this study. Second, it was limited to student teachers in the ELTEPs of Yemen. The findings would have been different if this 
study had aimed for teacher educators at the same ELTEPs. A similar study on teacher educators' perceptions of TPACK self-efficacy is also recommended for further investigation.

\section{Acknowledgments}

The author is grateful to the US Department of State and the Fulbright Program for funding and sponsoring CALLP. $\mathrm{He}$ is also appreciative of EFL student teachers' time and effort to partake in the study.

\section{References}

Admiraal, W., van Vugt, F., Kranenburg, F., Koster, B., Smit, B., Weijers, S., \& Lockhorst, D. (2016). Preparing preservice teachers to integrate technology into K-12 instruction: evaluation of a technology-infused approach. Technology, Pedagogy and Education, 26(1), 105-120. https://doi.org/10.1080/1475939x.2016.1163283

Akayoğlu, S. (2017). Perceptions of pre-service English teachers towards computer assisted language learning course. İlköğretim Online, 16(3), 1220-1234. doi: 10.17051/ilkonline.2017.330252

Alotumi, M. (2020). EFL learning beyond the wall with MALL: College students' perceptions. In R. Ahmed, A. Alkadi, \& T. Hagar (Eds.), Enhancements and limitations to ICT-based informal language learning: Emerging research and opportunities (pp. 138-160). IGI Global.

Bandura, A. (1994). Self-efficacy. In V. S. Ramachaudran (Ed.), Encyclopedia of human behavior (Vol. 4, pp. 71-81). Academic Press.

Baser, D., Kopcha, T. J., \& Ozden, M. Y. (2015). Developing a technological pedagogical content knowledge (TPACK) assessment for pre-service teachers learning to teach English as a foreign language. Computer Assisted Language Learning, 29(4), 749-764. https://doi.org/10.1080/09588221.2015.1047456

Beatty, K. (2010). Teaching and researching computer-assisted language learning (2nd ed.). Pearson Education Limited.

Bostancığlu, A., \& Handley, Z. (2018). Developing and validating a questionnaire for evaluating the EFL 'Total PACKage': Technological pedagogical content knowledge (TPACK) for English as a foreign language (EFL). Computer Assisted Language Learning, 31(5-6), 572-598. https://doi.org/10.1080/09588221.2017.1422524

Chambers, A., \& Bax, S. (2006). Making CALL work: Towards normalization. System, 34(4), 465-479. https://doi.org/10.1016/j.system.2006.08.001

Cohen, J. (1992). A power primer. Psychological Bulletin, 112(1), 155-159. https://doi.org/10.1037/00332909.112.1.155

Cohen, L., Manion, L., \& Morrison, K. (2018). Research methods in education (8th ed.). Routledge.

Creswell, J. W., \& Creswell, J. D. (2018). Research design: Qualitative, quantitative, and mixed methods approaches (5 ed.). SAGE Publication, Inc.

Cumming, G. (2012). Understanding the new statistics: Effect sizes, confidence intervals, and meta-analysis. Routledge.

El Shaban, A., \& Egbert, J. (2018). Diffusing education technology: A model for language teacher professional development in CALL. System, 78, 234-244. https://doi.org/10.1016/j.system.2018.09.002

Ersanli, C. Y. (2016). Improving technological pedagogical content knowledge (TPACK) of pre-service English language teachers. International Education Studies, 9(5), 18-27. https://doi.org/10.5539/ies.v9n5p18

Fathi, J., \& Ebadi, S. (2020). Exploring EFL pre-service teachers' adoption of technology in a CALL program: obstacles, motivators, and maintenance. Education and Information Technologies, 25(5), 3897-3917. https://doi.org/10.1007/s10639-020-10146-y

Hlas, A. (2017). Student teachers and CALL: Personal and pedagogical uses and beliefs. Calico Journal, 34(3), 336354. https://doi.org/10.1558/cj.26968 
Ince, M. (2017). The analysis of EFL teachers' perceptions of CALL and variables influential on teachers' attitudes. Journal of Narrative and Language Studies, 5(8), 59-72. https://www.nalans.com/nalans/article/view/49

İşler, C., \& Yıldırım, O. (2018). Perceptions of Turkish pre-service EFL teachers on their technological pedagogical content knowledge. Journal of Education and Future, 13, 145-160. https://search.proquest.com/openview/6e177c91c29fcc0d1c9c93023d6dc20b/1.pdf?pq$\underline{\text { origsite }=\text { gscholar } \& \mathrm{cbl}=2030900}$

Jeong, K. O. (2017). Preparing EFL student teachers with new technologies in the Korean context. Computer Assisted Language Learning, 30(6), 488-509. https://doi.org/10.1080/09588221.2017.1321554

Joo, Y. J., Park, S., \& Lim, E. (2018). Factors influencing pre-service teachers' intention to use technology: TPACK, teacher self-efficacy, and technology acceptance model. Educational Technology \& Society, 21(3), 48-59. https://www.jstor.org/stable/26458506

Kartchava, E., \& Chung, S. (2015). Pre-service and in-service English as a second language teachers' beliefs about the use of digital technology in the classroom. Studies in English Language Teaching, 3(4), 355-383. https://doi.org/10.22158/selt.v3n4p355

Kent, A. M., \& Giles, R. M. (2017). Pre-service teachers' technology self-efficacy. SRATE Journal, 26(1), 9-20. https://eric.ed.gov/?id=EJ1134392

Kessler, G. (2018). Technology and the future of language teaching. Foreign Language Annals, 51(1), 205-218. https://doi.org/10.1111/flan.12318

Kessler, G., \& Hubbard, P. (2017). Language teacher education and technology. In C. A. Chapelle \& S. Sauro (Eds.), The handbook of technology and second language teaching and learning (pp. 278-292). Wiley. https://doi.org/10.1002/9781118914069.ch19

Koehler, M. J., Mishra, P., \& Cain, W. (2017). What is technological pedagogical content knowledge (TPACK)? Journal of Education, 193(3), 13-19. https://doi.org/10.1177/002205741319300303

Koh, J. H. L. (2011). Computer skills instruction for pre-service teachers: A comparison of three instructional approaches. Computers in Human Behavior, 27(6), 2392-2400. https://doi.org/10.1016/j.chb.2011.08.002

Koh, J. H. L., \& Chai, C. S. (2014). Teacher clusters and their perceptions of technological pedagogical content knowledge (TPACK) development through ICT lesson design. Computers \& Education, 70, 222-232. https://doi.org/10.1016/j.compedu.2013.08.017

Kwangsawad, T. (2016). Examining EFL pre-service teachers' TPACK trough self-report, lesson plans and actual practice. Journal of Education and Learning, 10(2), 103-108. doi: 10.11591/edulearn.v10i2.3575

Lai, C., Shum, M., \& Tian, Y. (2014). Enhancing learners' self-directed use of technology for language learning: the effectiveness of an online training platform. Computer Assisted Language Learning, 29(1), 40-60. https://doi.org/10.1080/09588221.2014.889714

Le, N., \& Song, J. (2018). TPACK in a CALL course and its effect on Vietnamese pre-service EFL teachers. Asian EFL Journal, 20(9-1), 31-56.

Lee, K., Yan, A., \& Joshi, K. (2011). Understanding the dynamics of users' belief in software application adoption. International Journal of Information Management, $31(2), \quad$ 160-170. https://doi.org/10.1016/j.ijinfomgt.2010.07.009

Mei, B., Brown, G. T. L., \& Teo, T. (2017). Toward an understanding of pre-service English as a foreign language teachers' acceptance of computer-assisted language learning 2.0 in the People's Republic of China. Journal of Educational Computing Research, 56(1), 74-104. https://doi.org/10.1177/0735633117700144

Mishra, P., \& Koehler, M. J. (2006). Technological pedagogical content knowledge: A framework for teacher knowledge. Teachers College Record, 108(6), 1017-1054. https://www.learntechlib.org/p/99246/ 
Mohammadzadeh, B., \& Salem, N. (2018). A study on the integration of ICT by EFL teachers in Libya. Eurasia Journal of Mathematics, Science and Technology Education, 14(7), 2787-2801. https://doi.org/10.29333/ejmste/90594

Murray, D. E. (2017). Should we offer a CALL course? In J.-B. Son \& S. Windeatt (Eds.), Language teacher education and technology: Approaches and practices (pp. 169-183). Bloomsbury Academic. https://doi.org/10.5040/9781350020436.ch-011

Park, M., \& Son, J. B. (2020). Pre-service EFL teachers' readiness in computer-assisted language learning and teaching. Asia Pacific Journal of Education, 1-15. https://doi.org/10.1080/02188791.2020.1815649

Pegrum, M. (2014). Mobile learning: Languages, literacies and cultures. Palgrave Macmillan. https://doi.org/10.1057/9781137309815

Prasojo, L. D., Mukminin, A., Habibi, A., Marzulina, L., Sirozi, M., \& Harto, K. (2018). Learning to teach in a digital age: ICT integration and EFL student teachers' teaching practices. The Journal of Teaching English with Technology, 18(3), 18-32. https://www.tewtjournal.org/?wpdmact=process\&did=NTQ1LmhvdGxpbms

Rahimi, M., \& Pourshahbaz, S. (2019). English as a foreign language teachers' TPACK. IGI Global. https://doi.org/10.4018/978-1-5225-6267-2

Schmid, E. (2017). Teacher education in computer-assisted language learning. Bloomsbury Academic. https://doi.org/10.5040/9781474292788

Setyowati Ciptaningrum, D. (2017). The development of the survey of technology use, teaching, and technologyrelated learning experiences among pre-service English language teachers in Indonesia. Journal of Foreign Language Teaching and Learning, 2(2), 11-26. https://doi.org/10.18196/ftl.2220

Shulman, L. S. (2016). Those who understand: Knowledge growth in teaching. Educational Researcher, 15(2), 4-14. https://doi.org/10.3102/0013189x015002004

Son, J. B. (2018). Teacher development in technology-enhanced language teaching. Springer. https://doi.org/10.1007/978-3-319-75711-7

Tai, S. J. D. (2013). From TPACK-in-action workshops to English classrooms: CALL competencies developed and adopted into classroom teaching [Doctoral dissertation, Iowa State University]. ISU Digital Repository https://lib.dr.iastate.edu/etd/13335

Tai, S. J. D. (2015). From TPACK-in-action workshops to classrooms: CALL competency developed and integrated. $\begin{array}{lllll}\text { Language Learning } & \text { \& } & \text { Technology, } & 139(1), & 164 .\end{array}$ https://www.researchgate.net/publication/268147286_From_TPACK-inaction_workshops to classrooms_CALL_competency developed_and_integrated

Teo, T., Sang, G., Mei, B., \& Hoi, C. K. W. (2018). Investigating pre-service teachers' acceptance of Web 2.0 technologies in their future teaching: A Chinese perspective. Interactive Learning Environments, 27(4), 530546. https://doi.org/10.1080/10494820.2018.1489290

Torsani, S. (2016). CALL teacher education: Language teachers and technology integration. Sense Publishers. https://www.springer.com/gp/book/9789463004770

Tseng, J. J., Cheng, Y. S., \& Yeh, H. N. (2019). How pre-service English teachers enact TPACK in the context of web-conferencing teaching: A design thinking approach. Computers \& Education, 128, 171-182. https://doi.org/10.1016/j.compedu.2018.09.022

Turgut, Y., \& Boylan, M. (2017). Tracing pre-service English language teachers' perceived TPACK in sophomore, junior, and senior levels. Cogent Education, 4(1), 1-20. https://doi.org/10.1080/2331186x.2017.1368612 


\section{Appendix A. CALLP Outline}

\section{Description}

Supported by the US Department of State and sponsored by the Fulbright Program, the Computer-Assisted Language Learning Project (CALLP) introduces level-4 student teachers in the English Language Teacher Education Programs (ELTEPs) to CALL. CALLP renders five intensive 4-hour workshops that aim to orient the participants to CALL concepts and applications. The workshops are designed to engage student teachers in hands-on experiences with Web 2.0 tools and empower them to create their own multimedia CALL materials. Additionally, student teachers will review and evaluate some selected CALL applications and materials.

\section{Objectives}

By the end of CALLLP, EFL student teachers will be able to:

- grasp the underlying concepts and terminology of CALL;

- navigate different types of CALL materials;

- experiment with CALL applications;

- integrate CALL applications into their lesson plans in various ways;

- create their own multimedia CALL materials;

- review and evaluate selected CALL tools and materials; and

- seek CPD through CALL international associations and CALL SIGs of the international associations of TESOL, TEFL, etc.

CALLP content outline

\begin{tabular}{|c|c|c|c|}
\hline Workshop & Theme & Topic & Resources \\
\hline Workshop 1 & Orientation & $\begin{array}{l}\text { - Introducing CALL History } \\
\text { and Development } \\
\text { (Behavioristic CALL, } \\
\text { Communicative CALL, \& } \\
\text { Integrated CALL) } \\
\text { - Introducing MALL } \\
\text { - Word processing: spelling } \\
\text { checker, grammar checker, } \\
\text { thesaurus } \\
\text { - Google Documents } \\
\text { - Finding \& evaluating CALL } \\
\text { resources }\end{array}$ & $\begin{array}{l}\text { Beatty, K. (2010). Teaching and } \\
\text { researching computer-assisted } \\
\text { language learning. Harlow: } \\
\text { Longman. } \\
\text { Hubbard, P. (2011). Evaluation of } \\
\text { courseware and websites. In } \\
\text { L. Ducate \& N. Arnold (Eds.), } \\
\text { Present and future promises } \\
\text { of CALL: From theory and } \\
\text { research new directions in } \\
\text { foreign language teaching } \\
\text { (pp. 407-440). San Marcos, } \\
\text { TX: CALICO. } \\
\text { Pegrum, M. (2014). Mobile learning: } \\
\text { Languages, literacies and } \\
\text { cultures. London: Palgrave }\end{array}$ \\
\hline
\end{tabular}


Macmillan. doi:10.1057/9781137309815

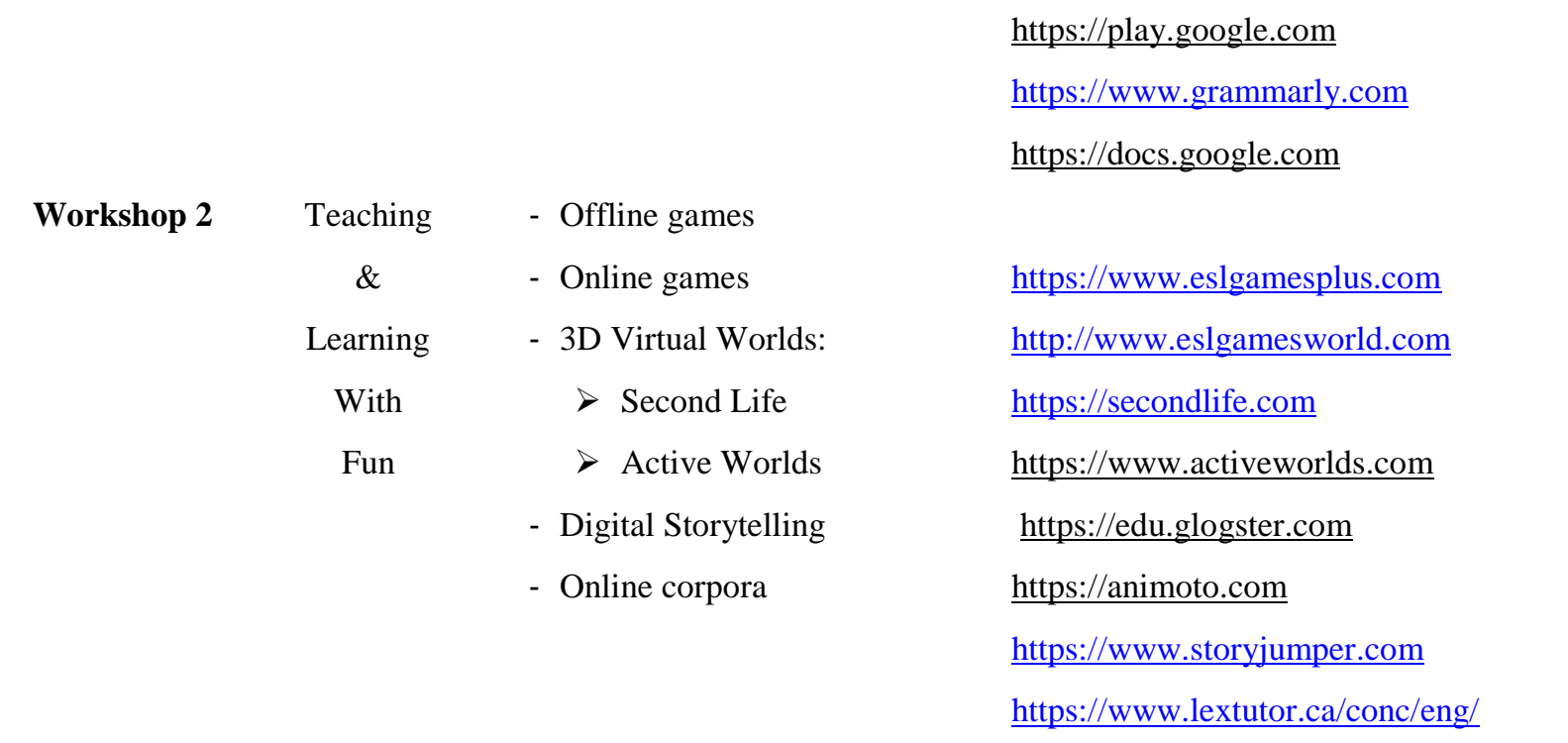

1. CALLP content outline (continued)

$\begin{array}{llll}\text { Workshop Theme Topic } & \text { Resources }\end{array}$

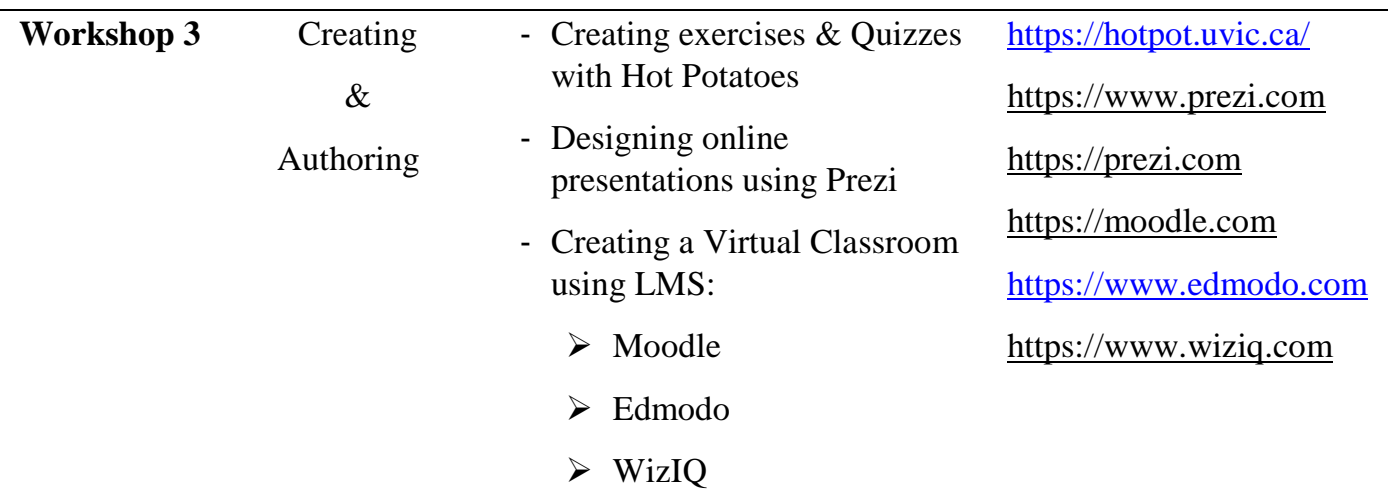

Workshop 4 Communicating - Computer Mediated

$\&$ Collaborating

\section{Communication (CMC)}

$$
\begin{aligned}
& >\text { Synchronous } \\
& >\text { asynchronous }
\end{aligned}
$$

- Message Boards, Forums, Instant Messaging Services \& VOIP

Yahoo: Group \& Messenger

Facebook: group \& messenger 
Skype

Google Hangouts

\begin{tabular}{|c|c|c|c|}
\hline \multirow[t]{15}{*}{ Workshop 5} & \multirow{5}{*}{$\begin{array}{l}\text { Publishing } \\
\qquad \& \\
\text { Continuing } \\
\text { Professional } \\
\text { Development } \\
\text { (CPD) }\end{array}$} & \multirow{2}{*}{$\begin{array}{l}\text { - Podcasting } \\
\text { - Blogging }\end{array}$} & \multirow{2}{*}{$\begin{array}{l}\text { https://soundcloud.com } \\
\text { https://archive.org }\end{array}$} \\
\hline & & & \\
\hline & & - Vlogging & https://www.youtub.com \\
\hline & & - Wikis & https://www.teachertube.com \\
\hline & & $\begin{array}{l}\text { - Creating and publishing a } \\
\text { web page }\end{array}$ & $\begin{array}{l}\text { https://mediawiki.org } \\
\text { https://www.blogger.com }\end{array}$ \\
\hline & & $\begin{array}{l}\text { - Online Communities of } \\
\text { Practice }\end{array}$ & https://www.wordpress.com \\
\hline & & - CALL Professional & http://www.wikidot.com \\
\hline & & Associations & https://www.pbworks.com \\
\hline & & - ESL/EFL Webinars & https://www.weebly.com \\
\hline & & - Using Twitter for CPD & https://www.youtub.com \\
\hline & & & https://sites.google.com \\
\hline & & & https://englishagenda.britishcouncil.org \\
\hline & & & http://evosessions.pbworks.com \\
\hline & & & http://www.efltalks.com \\
\hline & & & https://www.twitter.com \\
\hline
\end{tabular}




\section{Appendix B. Perceived TPACK Self-Efficacy Survey}

\section{Section (1). Background Information}

A. Name (optional):

B. Please put a check mark next to your answer of the following questions:

1. What is your age group?

20-25 ( ) 26-30 ( ) more than $30(\quad)$

2. What is your gender?

Male ( ) Female ( )

3. Are you willing to participate in an interview?
a. Yes $(\quad)$
b. No $(\quad)$

\section{Section (2). TPACK-EFL Questionnaire}

Instructions: Kindly indicate your perceived Technological Pedagogical Content Knowledge (TPACK) abilities as stated in each one of the statements below by circling the number that corresponds to your agreement/disagreement level with it. Please respond to all statements.

No.

Items

1. I can use basic technological terms (e.g. operating system, wireless connection, virtual memory, etc.) appropriately.

2. I can adjust computer settings such as installing software and establishing an Internet connection.

3. I can use computer peripherals such as a printer, a headphone, and a scanner.

4. I can troubleshoot common computer problems (e.g. printer problems, Internet connection problems, etc.) independently.

5. I can use digital classroom equipment such as projectors and smart boards.

6. I can use Office programs (i.e. Word, PowerPoint, etc.) with a high level of proficiency.

7. I can create multimedia (e.g. video, web pages, etc.) using text, pictures, sound, video, and animation.

8. I can use collaboration tools (Wiki, Edmodo, 3D virtual environments, etc.) in accordance with my objectives.

9. I can learn software that helps me complete a variety of tasks more efficiently.

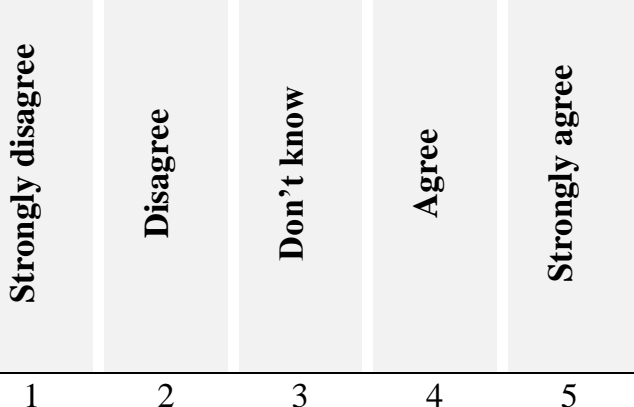


10. I can express my ideas and feelings by speaking in English.

11. I can express my ideas and feelings by writing in English.

12. I can read texts written in English with the correct pronunciation.

13. I can understand texts written in English.

14. I can understand the speech of a native English speaker easily.

15. I can use teaching methods and techniques that are appropriate for a learning environment.

16. I can design a learning experience that is appropriate for the level of students.

17. I can support students' learning in accordance with their physical, mental, emotional, social, and cultural differences.

18. I can collaborate with school stakeholders (students, parents, teachers, etc.) to support students' learning.

19. I can reflect the experiences that I gain from professional development programs to my teaching process.

20. I can support students' out-of-class work to facilitate their selfregulated learning.

21. I can manage a classroom-learning environment.

22. I can evaluate students' learning processes.

23. I can use appropriate teaching methods and techniques to support students in developing their language skills.

\begin{tabular}{l|l|l|l|l|}
\hline 1 & 2 & 3 & 4 & 5 \\
\hline 1 & 2 & 3 & 4 & 5 \\
\hline 1 & 2 & 3 & 4 & 5 \\
\hline 1 & 2 & 3 & 4 & 5 \\
1 & 2 & 3 & 4 & 5 \\
1 & 2 & 3 & 4 & 5 \\
\hline 1 & 2 & 3 & 4 & 5 \\
\hline 1 & 2 & 3 & 4 & 5
\end{tabular}

\begin{tabular}{|l|l|l|l|l|}
\hline 1 & 2 & 3 & 4 & 5 \\
\hline 1 & 2 & 3 & 4 & 5 \\
\hline
\end{tabular}

TPACK self-efficacy- (continued)

\begin{tabular}{|l|l|l|l|l|}
\hline 1 & 2 & 3 & 4 & 5 \\
\hline 1 & 2 & 3 & 4 & 5 \\
\hline 1 & 2 & 3 & 4 & 5 \\
\hline 1 & 2 & 3 & 4 & 5 \\
\hline
\end{tabular}

24. I can prepare curricular activities that develop students' language skills.

25. I can adapt a lesson plan in accordance with students' language skill levels.

26. I can take advantage of multimedia (e.g. video, slideshow, etc.) to express my ideas about various topics in English.

27. I can benefit from using technology (e.g. web conferencing and discussion forums) to contribute at a distance to multilingual communities.

28. I can use collaboration tools to work collaboratively with foreign persons (e.g. Second Life, Wiki, etc.).

29. I can meet students' individualized needs by using information technologies.

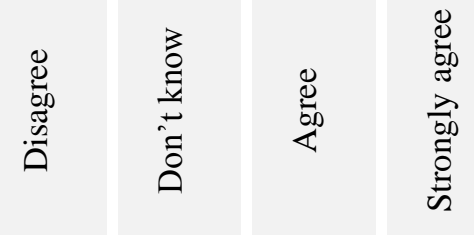

$\begin{array}{llllll}1 & 2 & 3 & 4 & 5 \\ 1 & 2 & 3 & 4 & 5 \\ 1 & 2 & 3 & 4 & 5\end{array}$


30. I can lead students to use information technologies legally, ethically, safely, and with respect to copyrights.

31. I can support students as they use technology such as virtual $\quad 1$ discussion platforms to develop their higher order thinking abilities.

32. I can manage the classroom-learning environment while using technology in the class.

33. I can decide when technology would benefit my teaching of specific English curricular standards.

34. I can design learning materials by using technology that supports students' language learning.

35. I can use multimedia such as videos and websites to support students' language learning.

36. I can use collaboration tools (e.g. wiki, 3D virtual environments, etc.) to support students' language learning.

37. I can support students as they use technology to support their development of language skills in an independent manner.

38. I can use Web 2.0 tools (animation tools, digital story tools, etc.) to develop students' language skills.

\begin{tabular}{l|l|l|l|l|}
\hline 1 & 2 & 3 & 4 & 5 \\
\hline 1 & 2 & 3 & 4 & 5 \\
\hline 1 & 2 & 3 & 4 & 5 \\
\hline 1 & 2 & 3 & 4 & 5 \\
\hline 1 & 2 & 3 & 4 & 5 \\
\hline 1 & 2 & 3 & 4 & 5 \\
\hline 1 & 2 & 3 & 4 & 5 \\
\hline
\end{tabular}




\section{Appendix C. Interview Question Form}

Name:

Gender: $\quad$ Male $\left(\ldots \_\right.$Female $\left({ }_{\ldots}\right.$ _ $)$

University:

Interview date and time:

(1) Do you think CALLP has helped you improve your technical knowledge of computer technologies? Why/why not?

(2) Do you think CALLP has helped you improve your knowledge of English language? Why /why not?

(3) Do you think CALLP has helped you improve your knowledge of teaching methods? Why/why not?

(4) Do you think CALLP has helped you improve your ability of using proper methods of EFL instruction? Why/why not?

(5) Do you think CALLP has helped you improve your ability of using technology to create, modify, and represent new content of English? Explain?

(6) Do you think CALLP has helped you improve your ability to integrate technology as part of your general teaching? If yes, in what way?

(7) Do you think CALLP has helped you improve your ability to grasp the interplay between technology, content, and pedagogy in your context, i.e. how to use technology to teach EFL? Tell me more, providing examples?

(8) I understand as part of the department curriculum, there are two technology-related courses, namely, computer course and educational technology course. Do you think those technology-related courses are sufficient to prepare you, as a future EFL teacher, to utilize CALL?

(9) Have your educators used CALL in their instruction? What computer applications have they used?

(10) What is your general impression of CALLP? How did it help your understanding of CALL? 


\section{Appendix D. Return and Valid Response Rates}

Table. Return rate and valid response rate of the survey $(N=400)$

\begin{tabular}{|c|c|c|c|c|c|c|c|c|c|c|c|c|}
\hline \multirow[b]{3}{*}{ University } & \multicolumn{6}{|c|}{ Pre-CALLP Questionnaire } & \multicolumn{6}{|c|}{ Post-CALLP Questionnaire } \\
\hline & \multicolumn{2}{|c|}{ Distributed } & \multicolumn{2}{|c|}{ Returned } & \multicolumn{2}{|c|}{ Valid } & \multicolumn{2}{|c|}{ Distributed } & \multicolumn{2}{|c|}{ Returned } & \multicolumn{2}{|c|}{ Valid } \\
\hline & No. & $\%$ & No. & $\%$ & No. & $\%$ & No. & $\%$ & No. & $\%$ & No. & $\%$ \\
\hline Sana'a & 100 & 100.00 & 100 & 100.00 & 95 & 95.00 & 100 & 100.00 & 100 & 100.00 & 96 & 96.00 \\
\hline Dhamar & 100 & 100.00 & 100 & 100.00 & 97 & 97.00 & 100 & 100.00 & 100 & 100.00 & 94 & 94.00 \\
\hline Ibb & 100 & 100.00 & 100 & 100.00 & 94 & 94.00 & 100 & 100.00 & 100 & 100.00 & 95 & 95.00 \\
\hline Hodeidah & 100 & 100.00 & 100 & 100.00 & 96 & 96.00 & 100 & 100.00 & 100 & 100.00 & 97 & 97.00 \\
\hline
\end{tabular}




\section{Appendix E. Statistical Analysis Methods}

Table. Statistical analysis methods used to answer the research questions

$\begin{array}{cc}\text { Research Question } & \text { Statistical } \\ \text { Method }\end{array}$

(11) What are the Yemeni EFL student teachers' perceptions of their TPACK selfefficacy pre-CALLP with reference to TPACK domains of CK, PK, PCK, TK, TCK, TPK, and TPACK?

Mean, standard deviation

(12) What are the Yemeni EFL student teachers' perceptions of their TPACK selfefficacy post-CALLP with reference to TPACK domains of CK, PK, PCK, TK, TCK, TPK, and TPACK?

Mean, standard deviation

(13) What are the Yemeni EFL student teachers' attributions of their increased or Frequency, decreased perceptions of TPACK self-efficacy?

percentage

(14) What are the Yemeni EFL student teachers' attributions of their increased or Frequency, decreased perceptions of TPACK self-efficacy? percentage 


\section{Appendix F. Normal Distribution and Outliers}

\section{Tests of Normality}

\begin{tabular}{|l|c|c|c|c|c|c|}
\hline & \multicolumn{3}{|c|}{ Kolmogorov-Smirnov } & \multicolumn{3}{c|}{ Shapiro-Wilk } \\
\cline { 2 - 7 } & Statistic & df & Sig. & Statistic & df & Sig. \\
\hline $\begin{array}{l}\text { Difference_Post_Pre_CA } \\
\text { LLP_TPACK_EFL }\end{array}$ & .036 & 400 & .200 & .991 & 400 & .012 \\
\hline
\end{tabular}

*. This is a lower bound of the true significance.

a. Lilliefors Significance Correction

Figure 1. Tests of normality of pre-CALLP and post-CALL perceived TPACK self-efficacy score difference (SPSS screenshot)

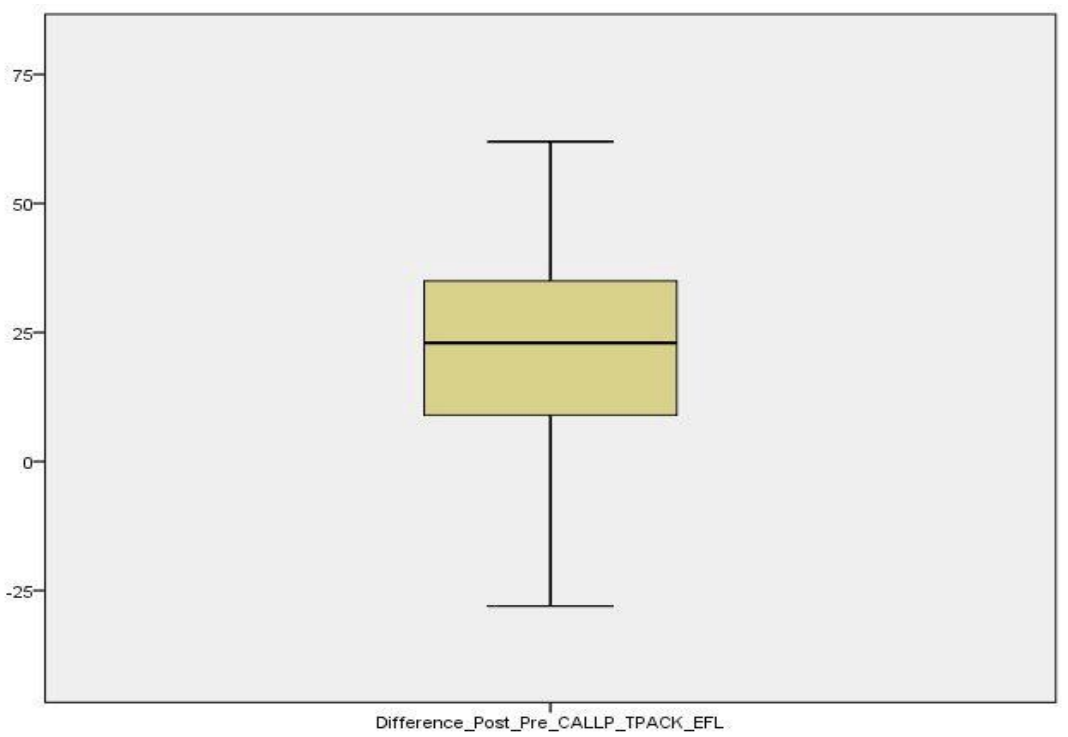

Figure 2. Outliers boxplot of pre-CALLP and post-CALL perceived TPACK self-efficacy score difference (SPSS screenshot) 


\begin{tabular}{|c|c|c|c|c|c|c|c|c|c|}
\hline \multicolumn{10}{|c|}{ Paired Samples Test } \\
\hline & & \multicolumn{5}{|c|}{ Paired Differences } & \multirow[b]{3}{*}{$t$} & \multirow[b]{3}{*}{ df } & \multirow[b]{3}{*}{ Sig. (2-tailed) } \\
\hline & & \multirow[b]{2}{*}{ Mean } & \multirow[b]{2}{*}{ Std. Deviation } & \multirow{2}{*}{$\begin{array}{l}\text { Std. Error } \\
\text { Mean }\end{array}$} & \multicolumn{2}{|c|}{$\begin{array}{l}\text { 95\% Confidence Interval of the } \\
\text { Difference }\end{array}$} & & & \\
\hline & & & & & Lower & Upper & & & \\
\hline Pair 1 & $\begin{array}{l}\text { TK_PostCALLP - } \\
\text { TK_PreCALLP }\end{array}$ & 4.495 & 5.695 & .285 & 3.935 & 5.055 & 15.785 & 399 & .000 \\
\hline Pair 2 & $\begin{array}{l}\text { CK_PostCALLP - } \\
\text { CK_PreCALLP }\end{array}$ & .425 & 3.201 & .160 & .110 & .740 & 2.656 & 399 & .008 \\
\hline Pair 3 & $\begin{array}{l}\text { PK_PostCALLP - } \\
\text { PK_PreCALLP }\end{array}$ & .360 & 2.759 & .138 & .089 & .631 & 2.609 & 399 & .009 \\
\hline Pair 4 & $\begin{array}{l}\text { PCK_PostCALLP - } \\
\text { PCK_PreCALLP }\end{array}$ & .400 & 3.227 & .161 & .083 & .717 & 2.479 & 399 & .014 \\
\hline Pair 5 & $\begin{array}{l}\text { TCK_PostCALLP - } \\
\text { TCK_PreCALLP }\end{array}$ & 2.315 & 2.658 & .133 & 2.054 & 2.576 & 17.421 & 399 & .000 \\
\hline Pair 6 & $\begin{array}{l}\text { TPK_PostCALLP - } \\
\text { TPK_PreCALLP }\end{array}$ & 8.135 & 5.413 & .271 & 7.603 & 8.667 & 30.058 & 399 & .000 \\
\hline Pair 7 & $\begin{array}{l}\text { TPACK_PostCALLP - } \\
\text { TPACK_PreCALLPP }\end{array}$ & 5.717 & 3.633 & .182 & 5.360 & 6.075 & 31.479 & 399 & .000 \\
\hline
\end{tabular}

Figure 3. Results of paired samples test for TPACK domains (SPSS screenshot) 